
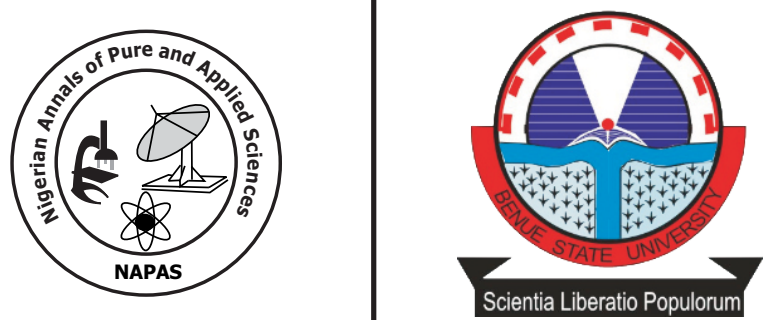

\title{
Ecological Survey of Aquatic Snails in Man-made and Natural Water bodies in Benue State.
}

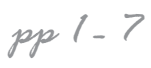

\author{
Okita, F.O., Omudu E.A. and Oche, A.M. \\ Department of Biological Sciences, \\ Benue State University, Makurdi, \\ Corresponding author:faithokita@gmail.com
}

\begin{abstract}
The epidemiological implications of fresh water snails have continued to pose serious challenge to schistosomiasis control. A survey was conducted to ascertain the species diversity and abundance of aquatic snails in man-made and natural water bodies in Benue state, Nigeria. Eight sites were sampled for the presence of snails using the sweep net and handpicking method. Snails captured were carefully placed into pre- labelled specimen bottles and transported to Benue State University Zoology Laboratory for identification. Plants commonly known to be suitable for snail attachment were collected and brought to the Botany laboratory for identification. The physiochemical parameters of the water were also documented. Data was processed using Analysis of Variance (ANOVA). A total of 1038 snails belonging to 3 species were identified; Melanoides tuberculata, 468 (45.1\%), Lanistes libycus 210 (20.2\%), Bulinus species 360 (34.7\%). Northbank dam harboured 2 (Bulinus and Melanoides) out of the 3 species recorded, making it the most favourable habitat sampled. Bulinus species was the most abundant in the natural habitats while it was replaced by Melanoides tuberculata in the man-made water bodies. ANOVA revealed a significant difference in relation to snail species encountered, and species abundance in habitats sampled $(\mathrm{P}<0.05)$. The predominant aquatic flora encountered were Ipoemoea aquatic and Nelsonia species. The study revealed that natural and man-made water bodies in Makurdi and Ochobo support the breeding of snail species that have serious epidemiological implications.
\end{abstract}

Key words: Ecology, aquatic snails, water bodies, Benue state. 


\section{Introduction}

Freshwater gastropods (snails) are an important and diverse component of aquatic ecosystems worldwide (Johnson et al. 2013). They are known to play significant roles in public and veterinary health in that they have been implicated in the transmission of a various diseases like Schistosomiasis, Fascioliasis, Paragonimiasis and Dicrocoeliasis. Of all these, schistosomiasis is of immense public concern globally with an estimated 218 million people at risk across 78 countries as at 2015 (WHO 2016). Nigeria is endemic with the infection, having approximately 101.28 million people at risk and 25.83 million people actually infected (Chitsul et al., 2000).

There is evidence of the disparity of habitats that serve as natural home for intermediate host snails. These cut across natural and man-made habitats such as rivers, lakes, road-side ponds, ditches amongst others (Phiri et al., 2007; Rollinson et al., 2003; Utzenger and Tarner 2001). The ability of these aquatic snails to inhabits diverse water bodies enhances the disease transmitting potentials of zoonotic species (Oladejo and Ofozie 2006; Schall and Diniz 2001).

Studies by Omudu and Iyough (2005) quipped that the network of freshwater system from river Benue provide ideal habitat for freshwater snails. Some of these snails have no history of serving as intermediate host of any disease, but some however have been implicated in the transmission. This research is designed to build on the existing baseline data by providing information on the current status of aquatic snail species abundance in fresh water bodies in Benue state, Nigeria.

\section{Methodology}

Study Areas: the sites selected for the study were 10 water bodies cutting across Makurdi and Ohimini Local Government Areas of Benue State, Nigeria. Makurdi, the headquarters of Benue state is located between latitude $7^{\circ} 38^{\prime} \mathrm{N}$ $7^{\circ} 50^{\prime} \mathrm{N}$, and longitude $8^{\circ} 24^{\prime} \mathrm{E}$ and $8^{\circ} 38^{\prime} \mathrm{E}$. It is situated in the Benue valley in the North Central region of Nigeria and is traversed by the second largest river in the Nigeria, the River Benue (Abah 2013). Makurdi is dominated with the guinea savanna vegetation, having an annual rainfall of between $150-18 \mathrm{~m}$ and a temperature of $26{ }^{\circ} \mathrm{C}-29^{\circ} \mathrm{C}$. Ochobo is a rural community located in Ohimini LGA of Benue State, which is bounded to the North and North East by Otukpo Local Government, South by Okpokwu Local Government and on the West by Ankpa and Olamaboro Local Government Areas of Kogi State. The inhabitants are predominantly farmers, fishers and petty traders who depend on River Okpokwu as their major water source.

Sampling: Snail samples were collected using scooping and handpicking methods described by Idris and Ajanusi (2002). Samples were collected with a long-handled snail sieve net (mesh size $3 \mathrm{~mm}-4 \mathrm{~mm}$ ). Snails were often seen near the edges of slightly deep waters or lodging in plant materials. The sieve net was dragged through the water thereby collecting snails clinging to the aquatic plants. Where sieve net could not be used, snails were handpicked with gloved hands, placed in prelabelled plastic specimen bottles and taken to Benue State University Zoology Laboratory for identification (Plates 1-5). Snail species were differentiated and identified using keys by Brown (1994) and Mandahl-barth (1965).

Aquatic plants to which snails were found clinging were collected and brought to the laboratory for identification (Omudu and Iyough 2005).

Physico-chemical characterisation of water: The physiochemical parameters of the water were also taken to include: water temperature, $\mathrm{pH}$, dissolved oxygen (DO) and water current (APHA 2005).

\section{Statistical Analysis}

The data generated from the study was analysed using Statistical Package for Social Sciences (SPSS) software, version 20. Analysis of variance (ANOVA) was used to reveal significant difference in the distribution and abundance of the snails at the different sample sites, and LSD was used as a posthoc test.

\section{Results}

The study encountered 5 different snail species in the eight locations sampled. These were in order of mean abundance: Melanoides tuberculata (58.5), Lanistes libyscus (26.3), Bulinus globosus (20.1), Bulinus truncates (13.4) and Bulinus forskalii (12.1). Northbank dam had the highest mean snail abundance and species diversity in that it was home to 4 out $f$ the 5 species identified. The drainage in BSU 
recorded the least, having just Lanistes libyscus (Table1).

The cumulative and monthly abundance of snail species collected is presented in figure 1 . There were variations in the monthly abundance of snail species collected although it collectively peaked in October and declined in December.

The effect of the physico-chemical parameters of the various snail habitats in respect to species abundance was analysed. Northbank dam had the richest species abundance with Mean $\mathrm{pH}$, Dissolved oxygen and Temperature of 7.28, 7.70, and 30.74, respectively. (Table 2).

There was a significant difference in the abundance of snails in natural and man-made habitats. M. tuberculata was highest (87\%) in man-made locations but least (13\%) in natural water bodies. Bulinus species $(68.3 \%)$ was highest in the natural habitats while there was no significant difference observed in the population of L. libyscus for both habitats (Figure 2).

The vegetative cover and the characteristics of the habitat were also documented. The aquatic flora of the habitats consisted of Ipomoea aquatica, Graminae species, Eclipta species, Nelsonia canescens, Ageratum conyzoides and Eluesine indica. Ipomoea aquatic was most abundant. (Table 3 )

Table 1: Overall distribution of aquatic snails collected in the sampled sites

\begin{tabular}{|c|c|c|c|c|c|c|}
\hline \multirow{2}{*}{ Site } & \multicolumn{3}{|c|}{ Snail species abundance } & \multirow[b]{2}{*}{ L.li } & \multicolumn{2}{|c|}{ Total } \\
\hline & B.fo & $B . g l$ & B.tr & & M. Tu & \\
\hline \multicolumn{7}{|l|}{ Man-made } \\
\hline Austoma & - & - & 15 & 31 & 15 & 61 \\
\hline BSU drainage & - & - & - & 38 & - & 38 \\
\hline BSUTH drainage & - & - & - & 31 & 3 & 34 \\
\hline North Bank dam & 17 & 40 & 2 & - & 389 & 488 \\
\hline \multicolumn{7}{|l|}{ Natural } \\
\hline Gyado Villa & - & - & 2 & 71 & - & 73 \\
\hline Industrial Layout & - & - & 34 & 15 & 28 & 77 \\
\hline River Benue bank & - & - & 14 & 24 & 33 & 71 \\
\hline River Okpokwu & 75 & 121 & - & - & - & 196 \\
\hline Total & 92 & 161 & 107 & 210 & 468 & 1038 \\
\hline Mean & 12.1 & 20.1 & 13.4 & 26.3 & 58.5 & \\
\hline
\end{tabular}

Bulinus globossus (B.gl); Bulinus forskalii (B.fo); Bulinus truncatus (B.tr); Lanistes libyscus (L.li); Melanoides tuberculata (M.tu)

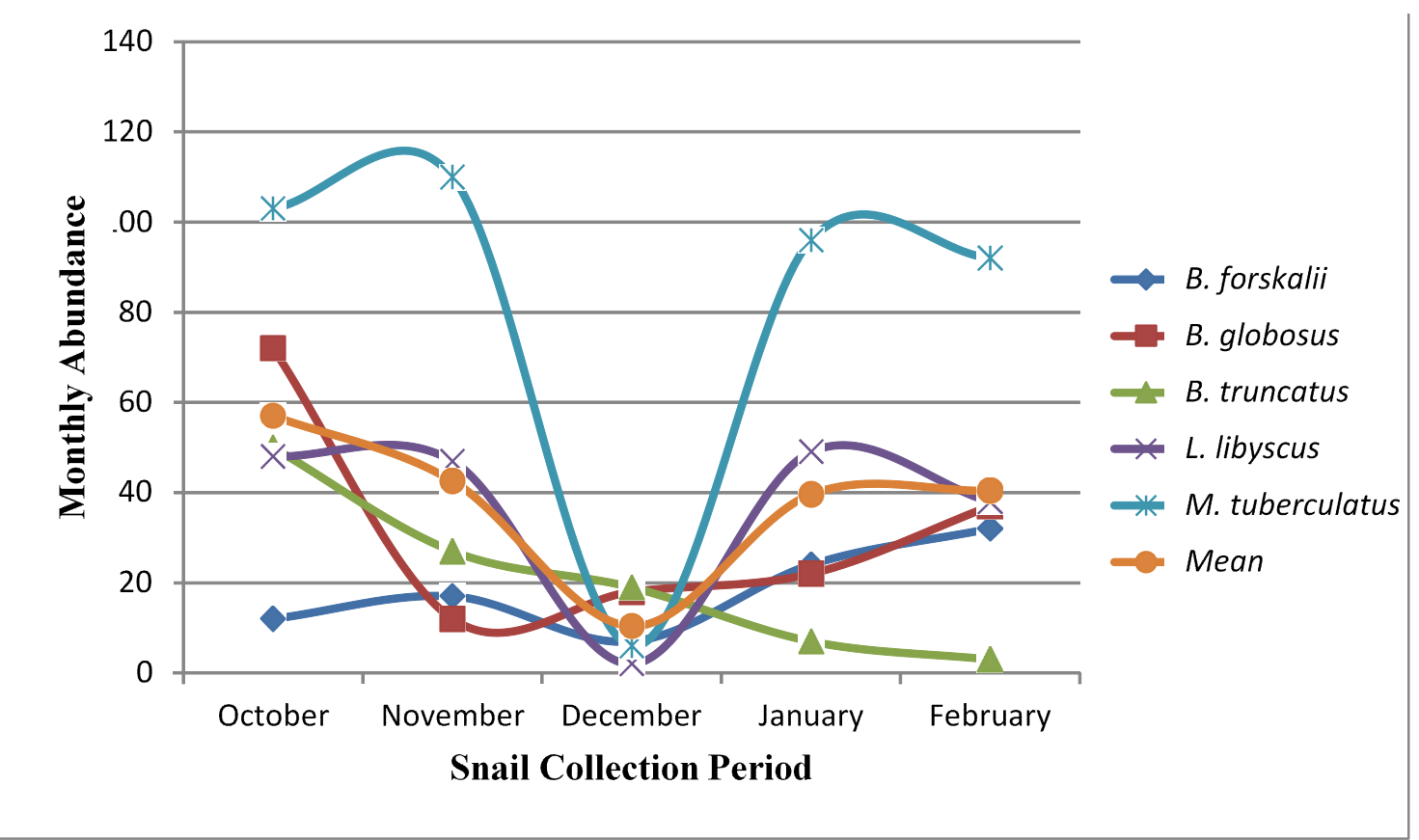

Figure 1: Monthly distribution of snail species from 0ctober 2016 to February 2017 
4 I Ecological Survey of Aquatic Snails in Man-made and Natural Water bodies in Benue State.

Table 2: snail species abundance in respect to physico-chemical parameters of the habitats

\begin{tabular}{|c|c|c|c|c|c|c|c|c|c|}
\hline \multirow[t]{2}{*}{ Location } & \multirow{2}{*}{$\begin{array}{c}\text { Mean } \\
\text { pH }\end{array}$} & \multirow{2}{*}{$\begin{array}{l}\text { Mean } \\
\text { DO }\end{array}$} & \multirow{2}{*}{\multicolumn{2}{|c|}{$\begin{array}{l}\text { Mean Water } \\
T^{0} \text { current }\end{array}$}} & \multicolumn{3}{|c|}{ Species availability } & \multirow[b]{2}{*}{ L.li } & \multirow[b]{2}{*}{ M.tu } \\
\hline & & & & & B.fo & B.gl & B.tr & & \\
\hline Austoma & 7.12 & 3.60 & 31.64 & ST & - & - & + & + & + \\
\hline BSU drainage & 7.16 & 3.70 & 32.20 & $\mathrm{SF}$ & - & - & - & + & - \\
\hline River Benue bank & 7.22 & 8.10 & 31.42 & MT & - & - & + & + & + \\
\hline Gyado Villa & 7.28 & 9.40 & 32.54 & ST & - & - & + & + & - \\
\hline Industrial Layout & 7.24 & 6.70 & 31.40 & $\mathrm{SF}$ & - & - & + & + & + \\
\hline North Bank dam & 7.28 & 7.70 & 30.74 & $\mathrm{SF}$ & + & + & + & - & + \\
\hline BSUTH drainage & 7.38 & 8.40 & 31.44 & $\mathrm{SF}$ & - & - & - & + & + \\
\hline Okpokwu river & 7.25 & 8.60 & 30.96 & MT & + & + & - & - & - \\
\hline
\end{tabular}

Bulinus globossus (B.gl); Bulinus forskalii (B.fo); Bulinus truncatus (B.tr); Lanistes libyscus (L.li); Melanoides tuberculata (M.tu)

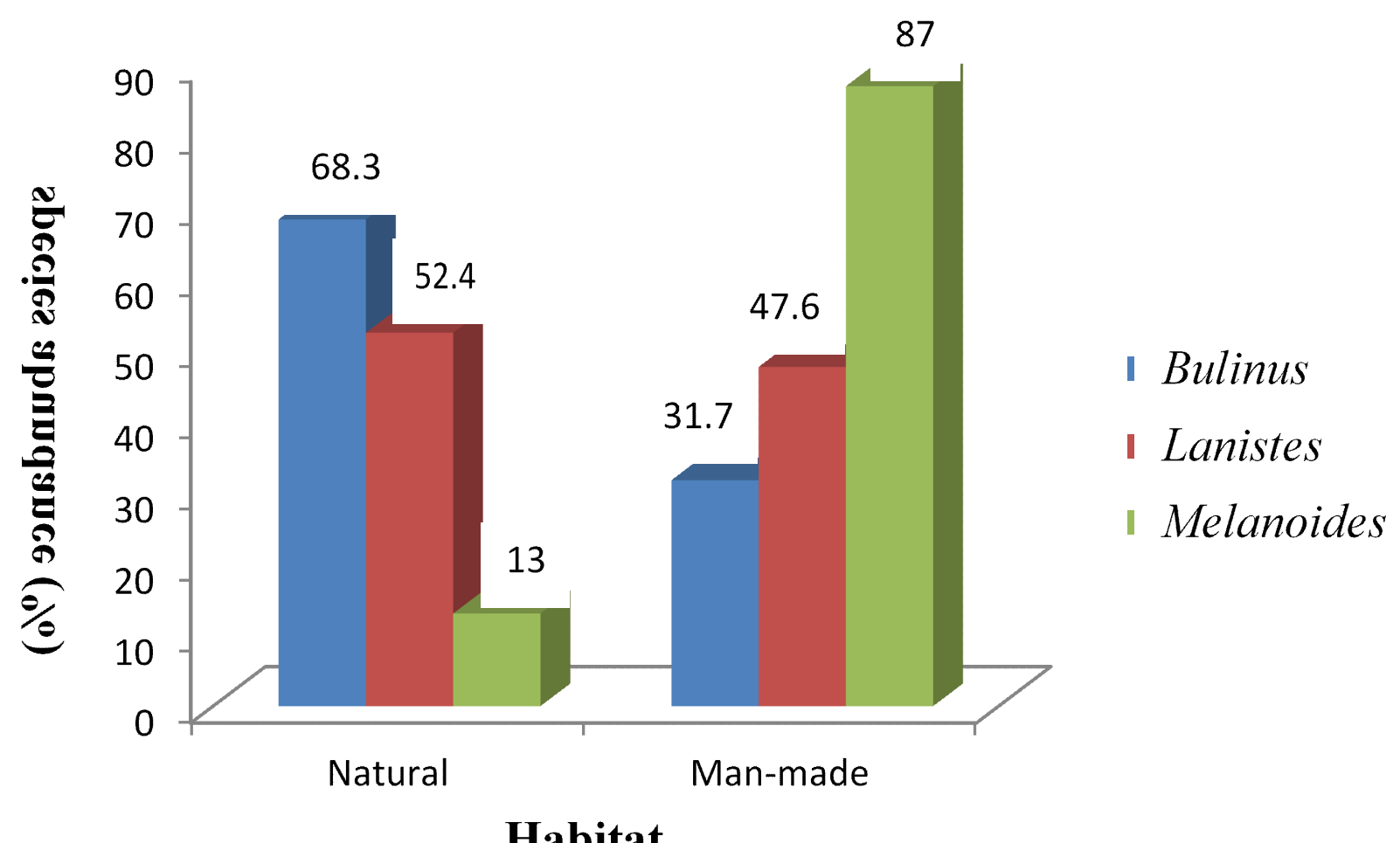

Figure 2: Variation in snail species abundance in Natural and man-made habitat 
Table 3: Snail species abundance, vegetative composition and characteristics of habitats

\begin{tabular}{|c|c|c|c|c|c|}
\hline $\begin{array}{l}\text { Site } \\
\text { No. }\end{array}$ & Site name & Description & $\begin{array}{l}\text { Water } \\
\text { contact } \\
\text { activity }\end{array}$ & Snail species & $\begin{array}{l}\text { Vegetative } \\
\text { composition }\end{array}$ \\
\hline 1. & Austoma & $\begin{array}{l}\text { Marshy area near } \\
\text { Austoma filling } \\
\text { station }\end{array}$ & $\begin{array}{l}\text { Rice } \\
\text { cultivation, } \\
\text { automobile } \\
\text { washing and } \\
\text { domestic use }\end{array}$ & $\begin{array}{ll}\text { Bulinus, } & \text { Lanistes, } \\
\text { Melanoides. } & \end{array}$ & $\begin{array}{l}\text { Ipomea, } \\
\text { graminae. }\end{array}$ \\
\hline 2. & $\begin{array}{l}\text { BSU First gate } \\
\text { drainage }\end{array}$ & $\begin{array}{l}\text { Man-made gutter in } \\
\text { front of BSU main } \\
\text { campus }\end{array}$ & $\begin{array}{l}\text { Fishing, snail } \\
\text { picking and } \\
\text { rice } \\
\text { cultivation }\end{array}$ & Lanistes & Ipomea \\
\hline 3. & Gyado villa & Stagnant pond & $\begin{array}{l}\text { Snail } \\
\text { collection, } \\
\text { domestic use, } \\
\text { fishing }\end{array}$ & Bulinus, Lanistes & $\begin{array}{l}\text { Ipomea, Eclipta } \\
\text { Nelsonia. }\end{array}$ \\
\hline 4. & Industrial layout & & & $\begin{array}{l}\text { Bulinus, } \\
\text { Melanoides }\end{array}$ & $\begin{array}{l}\text { Ipomea, } \\
\text { Nelsonia. }\end{array}$ \\
\hline 5. & $\begin{array}{l}\text { Teaching } \\
\text { hospital } \\
\text { drainage }\end{array}$ & $\begin{array}{l}\text { Man-made } \\
\text { drainage inside the } \\
\text { hospital premise }\end{array}$ & & Lanistes, Melanoides & $\begin{array}{l}\text { Ipomea, } \\
\text { Eluesine. }\end{array}$ \\
\hline 6. & Northbank dam & $\begin{array}{l}\text { Man-made water } \\
\text { reservoir }\end{array}$ & & Bulinus, Melanoides & $\begin{array}{l}\text { Ipomea, } \\
\text { Graminae, } \\
\text { Marselia. }\end{array}$ \\
\hline 7. & $\begin{array}{l}\text { Benue river } \\
\text { bank }\end{array}$ & & $\begin{array}{l}\text { Swimming, } \\
\text { irrigation, } \\
\text { farming, } \\
\text { domestic use, } \\
\text { fishing, } \\
\text { automobile } \\
\text { washing and } \\
\text { snail } \\
\text { collection }\end{array}$ & $\begin{array}{l}\text { Bulinus, } \quad \text { Lanistes, } \\
\text { Melanoids }\end{array}$ & $\begin{array}{l}\text { Ipomea, } \\
\text { Ageratum, } \\
\text { Nelsonia. }\end{array}$ \\
\hline 8. & Ochobo & $\begin{array}{l}\text { A tributary of } \\
\text { Benue River that } \\
\text { extends from } \\
\text { Okpokwu through } \\
\text { Ochobo in Ohimini } \\
\text { LGA }\end{array}$ & $\begin{array}{l}\text { Swimming, } \\
\text { domestic use, } \\
\text { fishing, } \\
\text { automobile } \\
\text { washing. }\end{array}$ & Bulinus & $\begin{array}{l}\text { Ipeomea } \\
\text { Eluesine }\end{array}$ \\
\hline
\end{tabular}
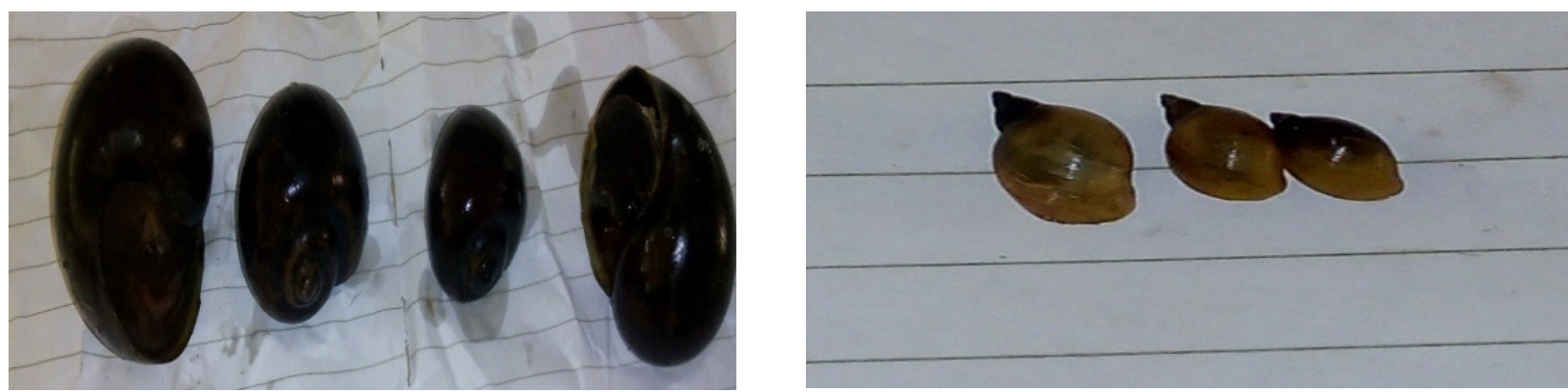


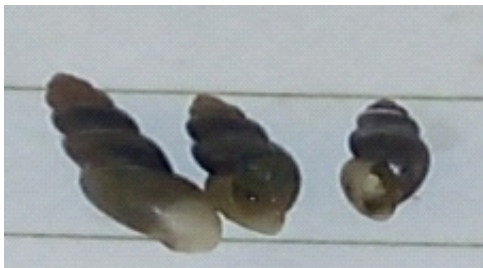

Plate 3: Bulinus forskalii

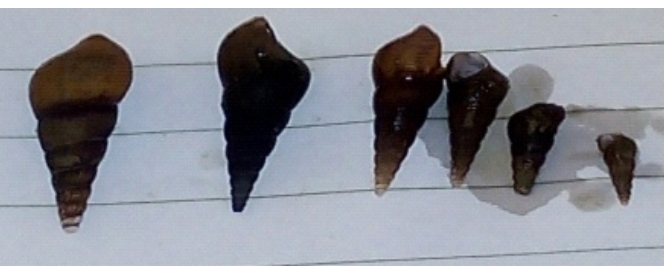

Plate 4: Melanoides tuberculata

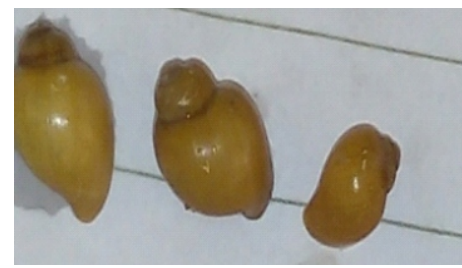

Plate 5: Bulinus truncatus

\section{Discussion}

There were five snail species encountered in this study with Melanoides tuberculatum being the most abundant species. This differs from reports from similar studies where Lanistes libyscus was the most abundant species recorded (Igbinosa et al., 2015; Omudu and Iyough 2005). The difference in the findings could be resulting from the season the research was conducted. Moreso, there is a similarity in the snails encountered in this study to those reported from other parts of Nigeria and Africa (Rabi 2017; Ntonifor and Ajayi 2007; Owojori etal., 2006).

There was a cumulative high abundance of Bulinus species in the study. Of the five species of snail encountered, Bulinus globosus is established as intermediate host of schistosomiasis in Nigeria (Oladejo and Ofoezie 2006). This further corroborates the works of other researchers on the endemicity of Benue State to schistosomiasis (Houmsou et al., 2012; Adulugba and Omudu 2013).

There was difference in snail species encountered in the various habitats sampled. Northbank dam had the highest species diversity with only Lanistes libyscus absent from the snail species collected. It has been documented that snail distribution in habitats is influenced by environmental factors such as rain, drought, water velocities, high temperatures and dessication (Igbinosa et al., 2015; Oladejo and Ofoezie 2006; Sturrock 2001).

The variation of physico-chemical parameters of the habitats investigated was not significant. This implies that the snails encountered were well adapted to the range of the conditions of the water bodies. This corroborates previous findings in Benue state and across Nigeria (Omudu and Iyough 2005; Agi and Okwunosa 2001). The study revealed that natural and man-made water bodies in Makurdi and Ochobo support the breeding of snail species that have serious epidemiological implications. This could pose a challenge to schistosomiasis vector or intermediate host control in these communities.

\section{References}

Abah, R. C. (2013). An application of geographic information System in mapping flood risk zones in a north central city in Nigeria. African Journal of Environmental science and technology, 7(6): 365-371.

Adulugba, A.O. and Omudu E.A. (2013). Epidemiological Studies of Schistosomiasis in Agatu LGA, Benue State, Nigeria. Nigerian Journal of Parasitology, 34: 12-18.

Agi, P. I. and Okwuosa, V. N. (2001). Aspects of water quality of freshwater systems harbouring snail vectors schistosome parasites in Jos, Nigeria. Journal of Aquatic Sciences, 16: 13-17.

American Public Health Association (APHA) (2005). Standard Methods forthe Examination of Water and Wastewater. 21st Edition, American Public Health Association, Washington DC, USA.

Brown, D.S. (1994). Freshwater Snails of Africa and Their Medical Importance. 2nd Edn., Taylor and Francis Ltd., England, Page: 609.

Chitsul, L., Engels, D., Monstresor, A. and Aavioli, L. (2000). The global status of schistosomiasis and its control. Acta Tropica, 77(1): 41-49.

Houmsou, R.S., Amuta, E.U. and Sar, T.T. (2012). Profile of an epidemiological study of urinary schistosomiasis in two Local Government Areas of Benue State, Nigeria. International Journal of Medicine and Biomedical Research

Igbinosa, B. I., Joshua, I. O., Okafor, F. C. and David, U. I. (2015). Ecological survey of freshwater ecosystems of Ovia, Edo State, Nigeria for gastropods molluscs. Animal Research International. 12(2): 2171-2177.

Mandahl-Barth, G. (1965). The species of the genus Bulinus, intermediate hosts of Schistosoma. Bulletin of World Health Organisation, 33: 33-44.

Ntonifor, H.N. and Ajayi, J.A. (2007). Studies on the ecology and distribution of some 
medically important freshwater snail species in Bauchi State, Nigeria. International Journal of Biological and Chemical Sciences, 1(2): 121-127.

Okpala, H.O., Nwobu, G.O., Agba, M.I. and Akor, J.O. (2003). Prevalence of schistosomiasis in wurukum, Makurdi local Government Area, Benue State, Nigeria. Journal of Medical Laboratory Science, 12(2): 47-51.

Oladejo, S. O. and Ofoezie, I. E. ( 2006). Unabated schistosomiasis transmission in Erinle River Dam, Osun State, Nigeria: evidence of neglect of environmental effects of development projects. Journal of Tropical Medical and International Health. 11(6):843-850.

Omudu, E. A. and Iyough, A. (2005). Ecological Studies of the gastropod fauna of some minor tributaries of river Benue in Makurdi, Nigeria. Animal Research International. 2(2): 306-310.

Owojori, O.J., Asaolu, S.O. and Ofoezie, I.E. (2006). Ecology of freshwater snails in Opa reservoir and esearch farm ponds in obafemi Awolowo University, Ile-Ife, Nigeria. Journal of Applied Sciences, 6(15):3004-3015.

Phiri, A.M., Phiri, I.K., Chota, A. and Monrad, J. (2007). Trematode infections in freshwater snails and catte from the kafue wetlands of Zambia during a period of highest catte-water contact. Journal of Helminthology, 81:85-92.

Rollinson, D., Stothard, J.R. and Southgate, V.R. (2003). Interactions between intermediate snail hosts of the genus Bulinus and schistomes of the Schistosoma haematobium group. Parasitology, 123: 65-72.

Schall, V. And Diniz, M.C.P. (2001). Information and education on schistosomiasis control: an analysis of the situation in the state of Minas Gerais, Brazil. Memorias do instituto Oswaldo Cruz, 96:35-43.

Sturrock, R.F. (2001). Schistosomiasis epidemiology and control: how did we get here and where should we go? Memorias do instituto Oswaldo Cruz, 96:17-27.

Utzenger, J. And Tanner, M. (2001). Microhabitat preferences of Biomphalaria pferfferi and Lymnea natalensis in a natural and man-made habitat in Southeastern Tanzania. Memorias do instituto Oswaldo Cruz, 96:323-328.

World Health Organization, "WHO schistosomiasis fact sheet," (2016). http://www.who.int/mediacentre/factshee ts/fs115/en. Retreived on 5th September, 